\title{
E-Cadherin Dysfunction and Cancer
}

\author{
María Fernanda Izaguirreㄹ, Carolina Daniela Galetto, Lautaro Baró1, Víctor Hugo Casco ${ }^{1,2}$ \\ ${ }^{1}$ Laboratorio de Microscopía Aplicada a Estudios Moleculares y Celulares, Facultad de Ingeniería, \\ Universidad Nacional de Entre Ríos, Oro Verde, Entre Ríos, República Argentina \\ ${ }^{2}$ Instituto de Investigación y Desarrollo en Bioingeniería y Bioinformática (IBB), \\ Consejo Nacional de Investigaciones Científicas y Tecnológicas (CONICET), CABA, República Argentina \\ Email: vcasco@ingenieria.uner.edu.ar, vcasco@bioingenieria.edu.ar
}

How to cite this paper: Izaguirre, M.F., Galetto, C.D., Baró, L. and Casco, V.H. (2019) E-Cadherin Dysfunction and Cancer. Journal of Biosciences and Medicines, 7, $42-67$.

https://doi.org/10.4236/jbm.2019.78004

Received: June 20, 2019

Accepted: August 18, 2019

Published: August 21, 2019

Copyright $\odot 2019$ by author(s) and Scientific Research Publishing Inc. This work is licensed under the Creative Commons Attribution International License (CC BY 4.0).

http://creativecommons.org/licenses/by/4.0/

\begin{abstract}
E-cadherin molecules are cell-cell molecular connectors, but also act attaching cell surface to the cytoskeleton through catenin's and additional partner proteins. Its main function is to regulate cellular adhesion and motility, and therefore acts as an invasion suppressor system. Its role is crucial in the induction and maintenance of cell polarity and differentiation, and in the organization and maintenance of tissue architecture. Downregulation or loss of its function is associated with an invasive and aggressive phenotype in many types of human cancers. In alterations of animal development, E-cadherin dysfunction influence in premature lethality or epidermal barrier and immunity defects. However, new hypothesis over its promoter role in tissue invasion is on focus. In addition to its tumor suppressor role, E-cadherin is a guiding molecule in collective cell migration increasing the metastasis risk during in vivo tumorigenesis. This E-cadherin function explains the retention of the functional E-cadherin expression, and that the epithelial-mesenchymal transition (EMT) is not required for the metastasis occurrence. However, like a switch, in some tumoral environments E-cadherin post-translational modifications may cause cell cluster migration. Like in development, in certain in vivo tumoral contexts, E-cadherin apparently involves signaling rather than cell contact formation. In this report, we explore the possibility of a novel role of thyroid hormones (THs) in the signal via E-cadherin-catenins, this not only should be involved in development and homeostasis, but also in cancer susceptibility of gastrointestinal tract.
\end{abstract}

\section{Keywords}

Cell Adhesion Molecules Complexes, E-Cadherin, Cancer, Thyroid Hormones 


\section{Introduction}

The disorganization of cellular adhesion and motility is one of the crucial factors responsible for tumor initiation and progression. The genes involved are also contributors to malignancy along with genes responsible for cell proliferation and survival.

Between the tumor suppressor genes, E-cadherin takes up a key place because most of human tumors are carcinomas derived from epithelial tissues, in which E-cadherin is the prototypic cell adhesion molecule, which functions by contact inhibition controlling cell survival and proliferation. Epithelial tumors often lose E-cadherin partially or completely as they progress toward malignancy [1] [2] [3] [4]. However, some cancers express normal or high levels of E-cadherins, such as epithelial ovarian cancer [5] [6] or inflammatory breast cancer [7] [8]. The loss of E-cadherin expression in association with the EMT often occurs during tumor metastasis. However, carcinomas and distal metastasis may retain E-cadherin expression [9] [10], and the EMT is not required for the metastasis occurrence [11]-[15]; in fact, clusters of tumor cells give rise to mammary metastasis [16] [17].

It is known that E-cadherin is involved in collective cell migration facilitating invasion and metastasis [10] [18]. It has been proposed that Rab11 acts cooperatively with E-cadherin in the promotion of collective cell migration, possibly also mediated by Rac1 activation and matrix metalloproteinase- 2 expression and indicates a poor prognosis in colorectal carcinoma [19]. Therefore, changes in E-cadherin function other than complete loss of expression may be important for these processes. In this sense, Petrova et al. [20] have proposed that E-cadherin adhesive activity in cancer cells can be regulated at the cell surface by an inside-out signaling mechanism probably involving allosteric regulation of the homophilic adhesive bond, analogous to integrin regulation [21] [22] [23]. Regulation of cadherin adhesive activity at the cell surface in response to growth factors has been shown to control tissue morphogenesis and epithelium formation [21] [24] [25]. Similar surface regulation has been proposed for C-cadherin in cell re-arrangements and tissue morphogenesis, during Xenopus gastrulation [24] [25] and for E-cadherin in epithelial cell migration and branching [21].

In cancer, the idea that adhesion proteins act as invasion suppressors is incompatible with many experimental and clinical observations. Cellular context, including post-translational modifications and protein turnover, may critically regulate junction dynamics and cell motility and can collaborate with the microenvironment to alter tissue-level phenotypes [26].

\section{E-Cadherin Dysfunction in the Adulthood}

Different mechanisms for E-cadherin inactivation in malignant tumors include mutations, epigenetic silencing, and increased endocytosis and proteolysis (Table 1).

Thus, knowing the mechanisms that regulate the epithelial polarity and 
Table 1. Representative abnormalities of E-cadherin. Based on [4] [65] [69].

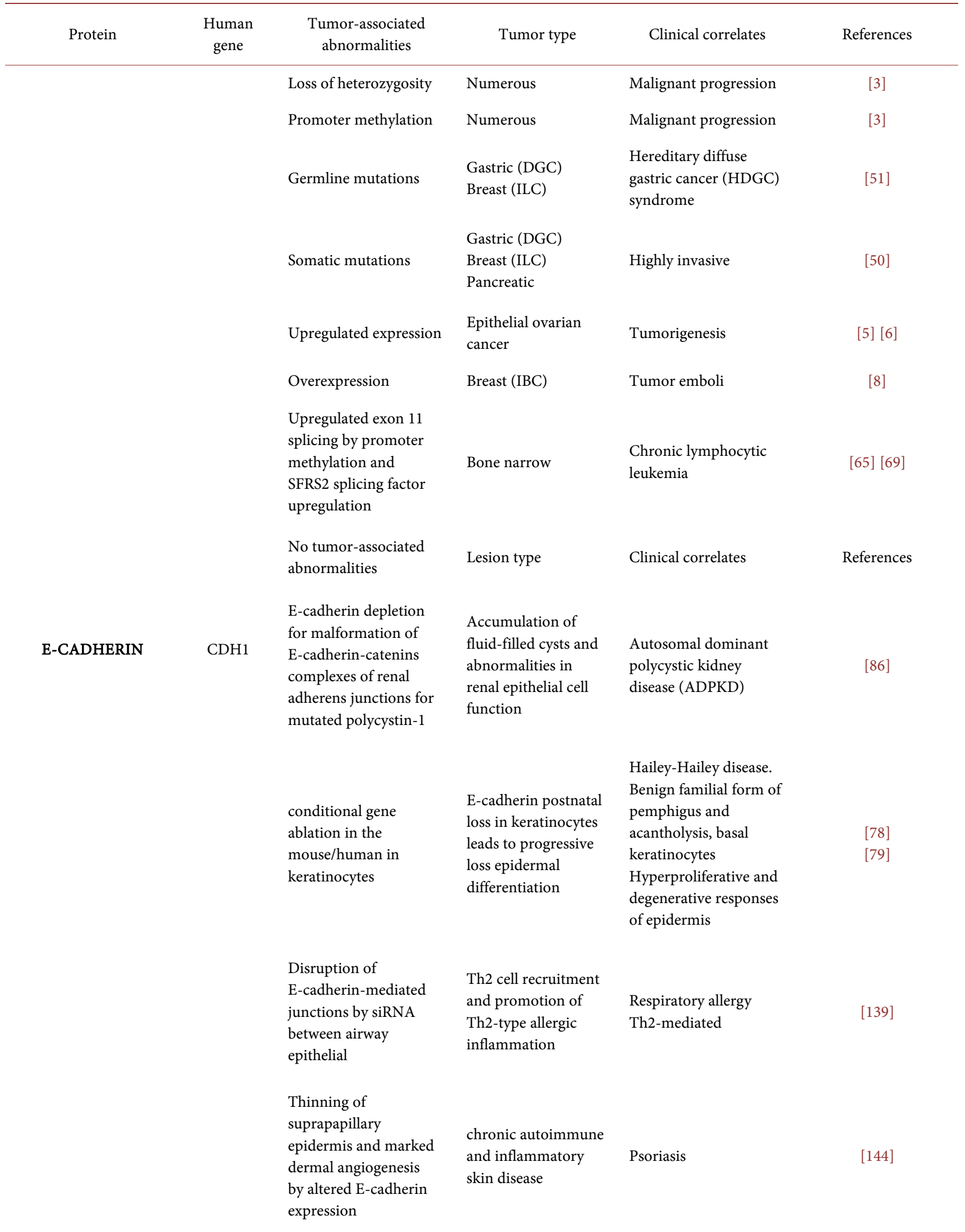

References: DGC: Diffuse gastric carcinoma; IBC: Inflammatory breast carcinoma; ILC: Invasive lobular carcinoma. 
molecules involved in it, such as E-cadherin and $\beta$-catenin, will help to unravel the mechanisms that control the phenotype, mobility and aggressiveness of tumoral cells [27]. The tissue progress from a physiological state in which the growth and differentiation rate are normally regulated, to a pathological, hyperplastic and invasive state, frequently involve a decrease or E-cadherin miss-localization and nuclear trans-localization of $\beta$-catenin. Nuclear $\beta$-catenin, in turn, activates target genes involved in cellular proliferation and metastasis processes [28]-[33] (Figure 1).

\subsection{E-Cadherin in Epithelia Establishing and Maintenance}

Both in developmental and adult epithelia, E-cadherins are the main molecules involved in the establishment and maintenance of adherens junctions (AJs). These are molecular complexes highly organized, where E-cadherin allows the cells to contact each other, and also modulate the organization of actin submembrane cortex [34] [35] [36] [37] and microtubules network [38] [39]. Both chemical and mechanic signals generated in the adhesive contact sites can act transducing through E-cadherin cytoplasmic domain to the nucleus, modifying the gene expression [37] [40]-[46].

Epithelial physiology depends not only of E-cadherin expression level [4] [47] [20], but also of its functionality in the cell surface. Epithelial AJs can weaken by mutations in E-cadherin gene, which decrease E-cadherin in the cell surface, and by changes in the phosphorylation level of adhesive complex molecules [44] [48] (Figure 1).

\subsection{E-Cadherin Mutations}

Somatic CDH1 gene mutations are the most common alterations in scattered cancers, such as diffuse gastric and lobular breast cancer, generating E-cadherin alterations detectable in about $50 \%$ of patients [49] [50]. Sixty-nine somatic mutations of the $\mathrm{CDH} 1$ gene and few miss sense mutations (mainly splice site and nonsense truncated mutations) have been reported [50]. Major difference in mutation type between diffuse gastric and infiltrative lobular breast cancers also has been detected. While the exon skipping with in-frame deletions is found in diffuse gastric tumors, most mutations found in infiltrating lobular breast cancers were out-of-frame mutations, which yield secreted truncated E-cadherin products. In most cases, these mutations occur in combination with loss of heterozygosity [4].

In addition, germline $\mathrm{CDH} 1$ gene mutations have been reported in familial gastric cancer [51] [52] [53], generating truncated E-cadherin protein in the signal peptide domain [54] or affecting the mechanism of inside-out cell surface regulation [20].

The number of mutations is growing daily (Genetic Home Reference, https://ghr.nlm.nih.gov/gene/CDH1). Therefore, the blockade of E-cadherin downregulation in tumors, could be one of the important approaches in future 


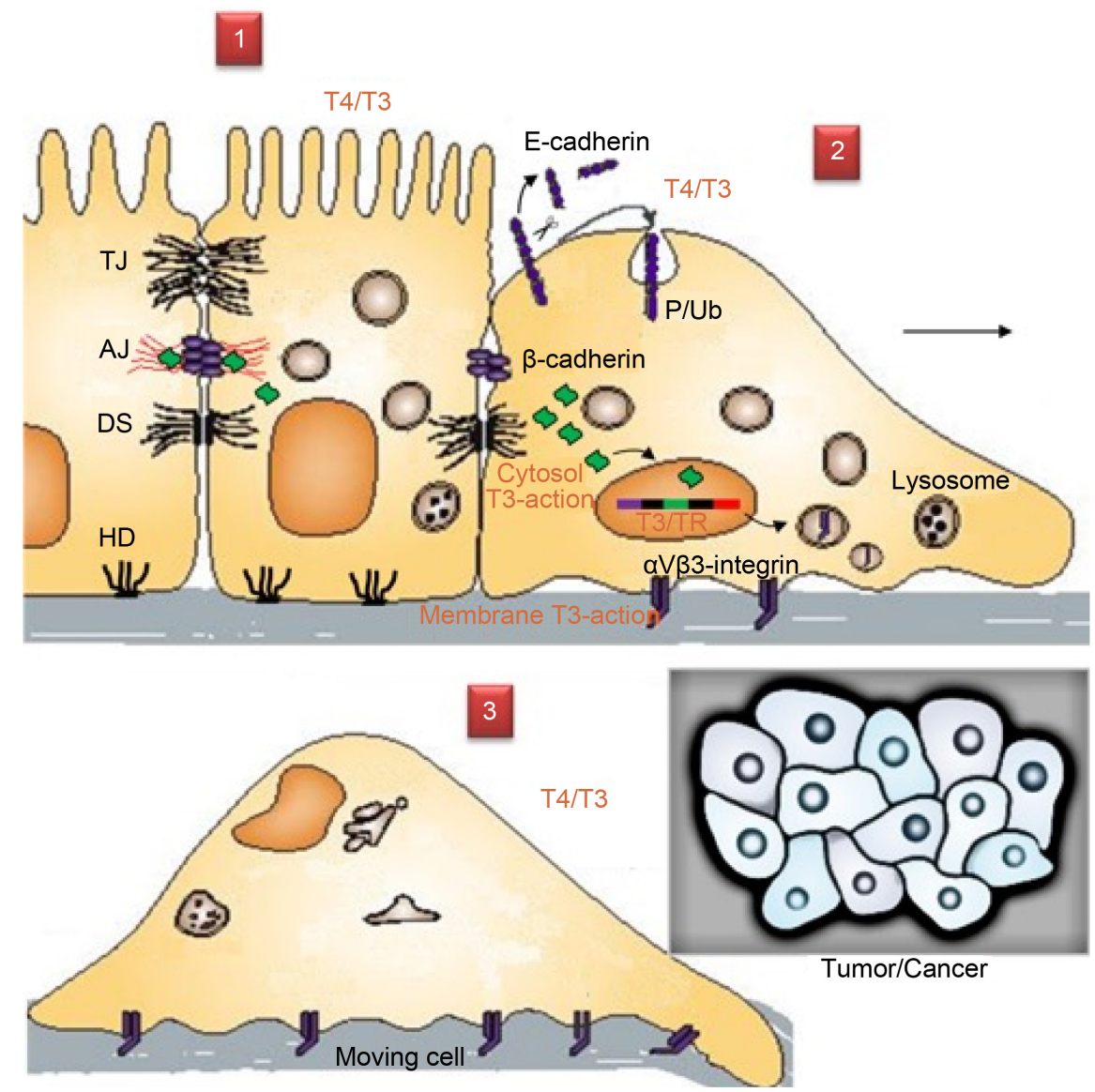

Figure 1. E-cadherin dysfunction and cancer. In a differentiated and established epithelium, the main function of E-cadherin is to regulate cellular adhesion and motility, and therefore acts as an invasion suppressor system (stage 1). Different mechanisms for E-cadherin inactivation in malignant tumors include mutations, epigenetic silencing, and increased endocytosis and proteolysis (stage 2). Downregulation or loss of its function is associated with an invasive and aggressive phenotype in many types of human cancers, because often occurs an EMT (stages 2 \& 3). The tissue progress from a physiological state in which the growing and differentiation rate are normally regulated for several growth factors to a pathological, hyperplastic and invasive state, frequently involve a decrease or E-cadherin miss-localization and nuclear trans-localization of $\beta$-catenin. Nuclear $\beta$-catenin in turn, activates target genes involved in cellular proliferation and metastasis processes, and cytoskeleton remodeling (stages $2 \& 3$ ). TJ: tight junction; AJ: adherens junction; DS: desmosome; HD: hemidesmosome; P: phosphorylated amino acid: Ub: ubiquitin tag; T4: 3,5,3',5'-tetraiodothyronine; T3: 3,5,3'-triiodothyronine; Colored nuclear segment: purple E-cadherin gene, green $\beta$-catenin gene, red $\alpha$-catenin gene; black TH-target gene others.

gene therapy. Targeting of this molecule could prevent the metastatic potential of almost any epithelial tumor. Nevertheless, it will not be an easy approach since its downregulation is caused by multiple mechanisms, ranging from mutations and gross deletions to gene transcription repression, as well as signal transduction through the E-cadherin adhesion complexes.

Mutation of calcium-binding sites leads to loss of the adhesive function of E-cadherin and proteolytic degradation or cytoplasmic miss localization [28]-[32], 
such as has been demonstrated in gastric carcinoma [55]. Most of the mutations affect the putative calcium-binding motif DTND [28], between EC2 and EC3 [48] [56].

CDH1 functional loss has been linked to diffuse-type gastric cancer susceptibility [54], being the germline inactivating CDH1 mutations characteristic of the hereditary diffuse gastric cancer syndrome [57]. E-cadherin deficiency initiates the gastric signet ring-cell carcinoma in humans and mice [58]. These mutations should be responsible for the scattered tumor cell morphology and highly invasive behavior typically associated with gastric cancer [48] [59] [60]. Additionally, in vitro studies have demonstrated that the carcinoma cell lines unable to express E-cadherin, as well as the use of antibodies and antisense RNAs against E-cadherin, increase the cell ability to invade collagen gels or tissues [61] [62] [63] [64], demonstrating the essential role of E-cadherin in the establishment of the nonmigratory cell phenotype in some tissue contexts.

A few years ago, a new mechanism of E-cadherin gene downregulation was uncovered, suggesting important roles during tumorigenesis. It is based on an aberrant E-cadherin transcript (nonfunctional RNA), lacking exon 11, that results in a frameshift, premature termination codon and upregulation of the $\mathrm{Wnt} / \beta$-catenin pathway in chronic lymphocytic leukemia (CLL) [65] (See [46]). These RNA transcripts are degraded by a nonsense-mediated decay pathway that is activated in all mammalian cells [66] [67] [68]. This E-cadherin gene inactivation mechanism in turn, results in fewer correctly spliced transcripts and so, a decreased E-cadherin expression. This alternative splicing also occurs in normal nonmalignant B lymphocytes, but the degree of exon 11 splicing in CLL is markedly upregulated [65]. Subsequently, Sharma et al. [69] found that this E-cadherin miss-splicing mechanism is activated in human tumor tissues, including breast, prostate and head and neck cancer, expressing the exon 11-skipped transcripts. Moreover, in tumor, both E-cadherin gene promoter methylation and SFRS2 splicing factor upregulation are involved in the E-cadherin miss-splicing [69].

These evidences support E-cadherin roles on control of the cell adhesion and motility, as well as, its position of a tumor/metastasis suppressor gene.

\section{E-Cadherin Dysfunction in Ontogenetic Development}

\subsection{E-Cadherin Dysfunction in Mammal Development}

During mammalian pre-implantation, E-cadherin mediates the compaction process and blastocyst formation, being an important player for the maintenance and function of epithelial cell layers at various stages [70] [71] [72]. Afterwards, the cadherin switching-downregulation of E-cadherin and its replacement by $\mathrm{N}$-cadherin, occurs during gastrulation and neurulation (also in tumorigenesis) [73] [74].

Homozygous CDH1-knockout mouse embryos die around the time of implantation, owing to the inability to form trophectodermal epithelium [75] [76]. 
Therefore, the conditional inactivation has been used to evaluate the function of E-cadherin during embryogenesis and organogenesis in mammary gland [77], skin [78] [79] [80] [81], and thyroid gland [82]. Some of these studies demonstrate that the postnatal loss of E-cadherin in mice epidermal keratinocytes results in the absence of AJs and improper cell differentiation, leading to progressive loss of hair follicles [78]. Others result in hyperplasia and hair follicle loss, as well as compensatory elevation of P-cadherin [79]. Notably, a more severe phenotype is observed when $\mathrm{CDH} 1$ is deleted from the mouse epidermis [81]. Loss of E-cadherin in the epidermis results in mice perinatal death, owing to an absence of epidermal barrier function as a consequence of faults in tight junction formation.

Variation of the observed phenotypes has been attributed to differences in the time points at which E-cadherin was inactivated [73]. However, new insights into E-cadherin function in epidermal sheet formation and maintenance have been obtained by combining conditional gene ablation and RNA interference [80]. Loss of mouse E-cadherin results in delayed epidermal sheet formation, and when P-cadherin is also suppressed, the defects extend to adherent junctions, desmosomes, tight junctions and cortical actin dynamics [80]. In the differentiating alveolar epithelial cells of mouse mammary glands, the $\mathrm{CDH} 1$ deletion results in massive cell death at the time of parturition, without tumorigenesis [77]. In contrast, the somatic inactivation of E-cadherin and p53 in mice leads to metastatic lobular mammary carcinoma through induction of anoikis resistance and angiogenesis [83]. Apparently, E-cadherin has a role in thyroid gland development but not in the maintenance of follicular cell adhesion [82].

In vitro studies show that $\mathrm{E}$-cadherin is not only necessary for $\mathrm{AJ}$ formation but also its adhesive activity is crucial for the assembly of other junctional complexes such as desmosomes, gap and tight junctions [84] [85]. These data suggest that initial cell-cell adhesion mediated by the cadherin complex is a key step in setting up other cell junctions, cell polarity, and three-dimensional tissue organization. Surprisingly, in vivo studies suggest an E-cadherin signaling role rather than adhesive in the stratified epithelium morphogenesis [81].

\subsection{E-Cadherin Dysfunction in Anuran Development}

To check the preceding hypothesis, we carry out an in vivo study by altering phosphorylation level of adhesion protein-complexes in toad tadpoles (Rhinella arenarum) via inhibition of protein tyrosine phosphatases [44]. Again, neither disassembly of epidermal cell junctions nor histological changes were observed, although when E-cadherins and $\beta$-catenins deeply modified their expression levels. Cells significantly decrease surface E-cadherin and the submembrane $\beta$-catenin, also modifying the expression pattern morphology, preserving $\mathrm{E}$ cadherin only in the puncta and increasing the cytosolic and nuclear $\beta$-catenin. The histological analysis did not reveal blistering or loss of cellular shape or tissue architecture, suggesting no major roles of E-cadherin in epidermal cell con- 
tact formation and maintaining in vivo. A possible explanation for this could be that the loss of E-cadherin would be offset by the transcriptional upregulation of "vicariant" adhesive molecules avoiding cell-cell contact disorganization, such as has been suggested by Roitbak et al. [86]. Interesting, E-cadherin gene inactivation in mouse produces perinatal death due to the inability to maintain a functional epidermal water barrier and reveals that the key tight junctional components were improperly established, resulting in altered tight junctional architecture and epidermal resistance [81]. Surprisingly, desmosomes and AJs were formed normally and no obvious defects in cell contacts were detected. This fact suggests that E-cadherin is specifically required for tight junctions but not for other contact formation. This apparently involves signaling rather than cell contact formation in vivo [81].

In addition, E-cadherin internalization and recycling at cell surface are a major route for remodeling and maintenance control of AJs [87] [88] [89], as well as its degradation via lysosomes [90] [91] [92]. There is evidence that a small pool of cell surface E-cadherin is constitutively and constantly trafficked through endocytosis and recycling. This pool is markedly increased in pre-confluent cells and when cell-cell contacts are weakened or disrupted by distinct mechanisms [87] [88]. Obviously, the decrease of cell surface E-cadherin and their cytosolic absence suggest that it is internalized and then shuttled to lysosomes via AJ-protein tyrosine phosphatase (PTP) inhibition [44]. Lysosomal targeting of E-cadherin is an important post-transcriptional mechanism to deplete cellular E-cadherin during Src-induced epithelial to mesenchymal transitions [90], whereas surface recycling targeting will be very important during organ and tissue remodeling, such as metamorphosis [45] [46] (Figure 1). Interesting, phospho-site mutations indicate that dephosphorylation of specific Ser/Thr residues in the $\mathrm{N}$-terminal domain of p120-catenin mediates adhesion activation mediated by E-cadherins [21]. Thus, physiological regulation of the adhesive state of E-cadherin involves physical and/or conformational changes in the EC interface regions of the ectodomain at the cell surface that are mediated by catenin-associated changes across the membrane.

\subsection{Animal Developmental Timing and E-Cadherin Functional Activity}

Substantial differences found on results between in vitro and in vivo studies, as well as on the time points at which E-cadherin is evaluated during morphogenesis and organogenesis, clearly suggest that E-cadherin and their linking-catenins have tissue- and cell context-specific roles depending of on animal-developmental timing. Thus, blocking antibodies against E-cadherin and catenins provoked notable alterations of early development [93] [94] [95]. Tail-bud embryos of Rhinella arenarum toad treated with anti-E-cadherin did not exhibit significant developmental delay, but suffer severe alterations, including shortening and folding of neural tube and notochord, deformed and ectopic pharynx and segmented somitogenic mesoderm, globular tail, malformed ear and eye vesicles, 
and apparent absence of heart tube and gills. Surprisingly, the epidermis seems to be normally developed [94]. Although E-cadherin is an epithelial marker, these results suggest differential roles of E-cadherin into epidermal ectoderm, neuroectoderm, endoderm and mesoderm, during early development. This is so, that in vitro and in vivo, E-cadherin maintains the pluripotency of embryonic stem cells [96]-[100].

In the Rhinella arenarum toad, it has been proposed that the epidermal and digestive tract E-cadherins establish exploring contacts at stage 15, transient contacts that increase from stage 17 onwards, and it turns into a zippering framework structure from stage 25 onwards, which coincides with the transition from embryonic into larval life [44] [45]. From stage 25 onwards, this framework increases and becomes organized in the puncta contacts between two or more cells. Even though, a drastic skin remodeling by the disassembling and reassembling of adhesive contacts is produced at the metamorphic climax, E-cadherin expression in cell boundaries is stable, when live larval, apoptotic larval, and live preadult cells coexist [44] [45] [46]. Functionally, the quick disassembly and the weak force associated at cadherin EC1 interaction could be advantageous in the early exploration phase of junctional remodeling that must occur during the establishment of the first tissue patterns [101] [102]. Afterwards, in the development, the continuous pattern and puncta observed could represent steady contacts, where the interaction between all cadherin-ectodomains should generate the force to stabilize the new tissue structure formed, which must be able to support strong tensions and deformations [44] [101] [103] [104]. It is known that the strong adhesion foundation by cadherins depends on their association with the actin cytoskeleton, a connection mediated by $\beta$ - or $\gamma$ - and $\alpha$-catenin [105], and on their surface stabilization mediated by $\mathrm{p}-120$-ctn [89]. Some studies demonstrate that the phosphorylation of $\beta$-catenin reduces their affinity for E-cadherin by approximately $85 \%$ [106] and increases the free cytosolic pool of $\beta$-catenin, regulating its function as a signaling molecule during epithelial cell migration [107]. Additionally, it is known that to reach a stable manner, it is necessary both to maintain a dephosphorylated pool of $\beta$-catenin as well as, low levels of free cytoplasmic $\beta$-catenin [108]. This state can be accomplished both by recruitment of active PTPs, and/or $\beta$-catenin-destruction multiprotein complexes [106] [109]. PTP inhibition promotes tyrosine phosphorylation of zonula adherens proteins, increasing the movement of macromolecules and neutrophils across the endothelium barrier [110]. Opening of the paracellular pathway theoretically permits disengagement of homophilically bound VE-cadherin ectodomains and lateral mobility in the lipid bilayer as a VE-cadherin-catenin complex. This would permit more dynamic and efficient zonula adherens disassembly/reassembly in response to rapidly changing physiological demands [109]. In contrast, PTP inhibition caused E-cadherin-disappearance of both membrane and cytosol suggesting lysosomal targeting, and $\beta$-catenin mobilization from AJs and activation of nuclear signal pathway [44]. Therefore, the mechanisms by which the tyrosine phosphorylation state of pro- 
teins of the zonula adherens act regulating both cadherin function and concentration remain poorly understood.

\subsection{Thyroid Hormones Influence in the E-Cadherin Cell Activity}

Searching for some of those physiological demands, which control the cell surface E-cadherin function and concentration, as well as some response to this dilemma, we analyzed the response to 3,5,3'-triiodothyronine (T3), a key hormone of vertebrate development, of E-cadherin, $\beta$-, $\alpha$ - and p120-catenin, and small proteins $\mathrm{G}$. We found morphometric and molecular evidences of positive gene control exerted by T3 on E-cadherin expression, as well as its cytoskeleton connecting proteins $\beta$ - and $\alpha$-catenin, and Rac1 in gut epithelial cell during anuran metamorphosis [45] [46] [111] [112]. Other studies also shown direct transcriptional upregulation of the mouse $\beta$-catenin gene by THs [113], and expression induction of type 2 deiodinase and E-cadherin by T3 [114].

Although when THs have a key role in the development of anurans, recently, it has been established that TH signaling is involved not only in development and homeostasis but also in cancer susceptibility in the mouse intestine [115]. Thus, in intestine, TR $\alpha 1$ binds directly both in vitro and in vivo, to $\beta$-catenin gene-intron 1 specific TRE sequence (TRE-int1) increasing its expression [113] (Figure 1). This positive control is an autonomous way and is parallel to positive regulation of proliferation-controlling genes such as type D cyclins and c-myc, which are well-known targets of the Wnt/ $\beta$-catenin pathway [113] (Figure 2). Moreover, Sirakov and Plateroti [115] shown in turn, that the increase of $\beta$-catenin/Tcf4 is correlated with reduction of TR $\alpha 1$ transcriptional activity on its target genes, and also that TRal activates and synergizes Wnt pathway, inducing crypt cell proliferation and promoting tumorigenesis [116]. Additionally, Guigon et al. [117] demonstrated a direct repression of the $\beta$-catenin gene by liganded $\operatorname{TR} \beta$ through interaction with negative TREs located in the CTNNB1 promoter (Figure 2). This trans-repression is mediated by interaction between $\operatorname{TR} \beta$ with Retinoid X Receptor ( $\operatorname{RXR} \beta$ ), and binding of complexes to TREs located in the human CTNNB1 promoter between -807 and -772 and consisting of two hexamers separated by 14 nucleotides. Thus, the liganded $\operatorname{TR} \beta$ acts as a tumor suppressor via expression inhibition of a potent tumor promoter, the CTNNB1 gene.

Even though TH signaling controls the proliferation of the intestinal epithelial progenitors in both amphibians and mammals, it has been suggested that in contrast to mammals, the $\mathrm{TH}$ control on the $\mathrm{Wnt} / \beta$-catenin pathway appears to dilute in amphibians [115] [118]. However, our studies in anuran gut (Rhinella arenarum and Xenopus laevis) suggests an important positive control of $\beta$-catenin, in addition to $\alpha$-catenin, E-cadherin and Racl small GTPase, during organ developmental remodeling [45] [46] [111] [112].

These and other data show a complex molecular network controlling tissue homeostasis. In mammals, THs also exert profound effects on fetal epidermal 


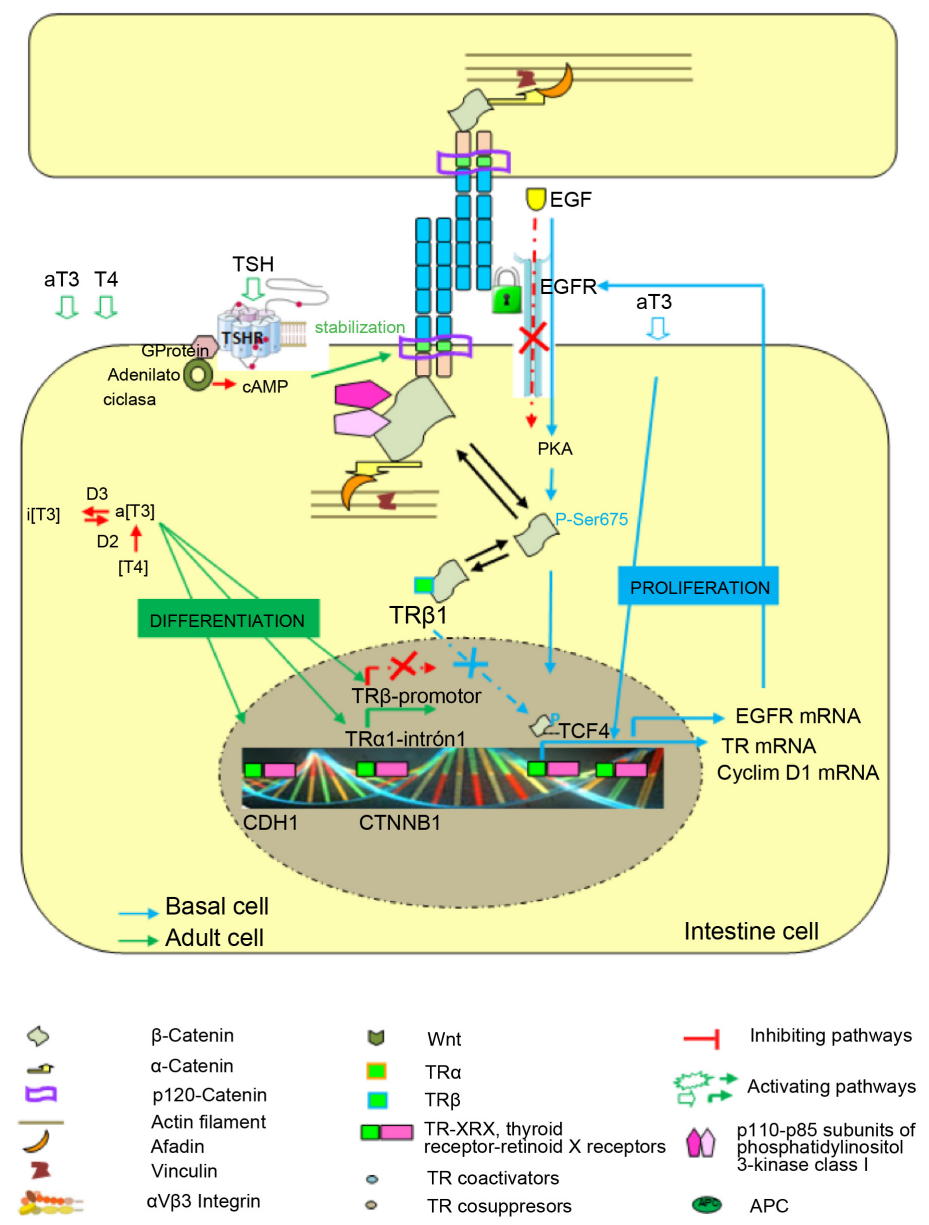

Figure 2. TH signaling is involved in development, homeostasis and cancer susceptibility in the mouse intestine. E-cadherin trans-interaction triggers activation of the phosphatidylinositol-3-kinase (PI3K)-Akt-protein kinase $\mathrm{B}$ pathway bound to $\beta$-catenin, generating phosphatidylinositol-(3,4,5)-triphosphate (PIP3), recruitment of guanine nucleotide exchange factors, activation of Racl or Cdc42 and Akt, and reduction of Rho activation. In addition, $\mathrm{TR} \alpha$ or $\mathrm{TR} \beta$ forms a cytoplasmic complex with the $\mathrm{p} 85$ subunit of PI3K, inducing protein kinase $\mathrm{B} /$ Akt nuclear translocation and inhibition of the $\mathrm{Wnt} / \beta$-catenin pathway through its interaction and consequent sequestration of $\beta$-catenin. The process results in down-regulation of cell proliferation. Simultaneously, T3 binding to TRs causes co-repressors are displaced and co-activator proteins are recruited to the ligand-bound TR complex, facilitating T3-dependent activation of the target genes. Besides, THs also exert rapid nongenomic actions that are initiated at the cell membrane mediated by integrin $\alpha \mathrm{v} \beta 3$, activating of the mitogen-activated protein kinase (MAPK) intracellular cascade, and thus modulating the membrane potential and actin cytoskeletal components anchored at the cell membrane. TH-activated MAPK, in turn, can rapidly translocate to the nucleus inducing serine phosphorylation of TRs, inducing angiogenesis or tumor cell proliferation. Nuclear targets for phosphorylated TRs include the transcription factors p53, STAT1a and STAT3, E-cadherin, $\beta$ - and $\alpha$-catenin, and TR $\alpha$ l bind to $\beta$-catenin gene-intron 1 . This positive control is parallel to that on type $\mathrm{D}$ cyclins and c-myc, which are known targets of the Wnt/ $\beta$-catenin pathway. In turn, the increase of $\beta$-catenin/Tcf4 is correlated with reduction of TR $\alpha 1$ transcriptional activity on its target genes, and TR $\alpha 1$ activates and synergizes Wnt pathway, inducing crypt cell proliferation and promoting tumorigenesis. Opposite exist a direct repression of the $\beta$-catenin gene by liganded $\operatorname{TR} \beta$ through interaction with negative TREs located in the CTNNB1 promoter. 
differentiation, barrier formation, hair growth, sebum production, wound healing, epidermal oxygen consumption, keratinocyte proliferation, and keratin gene expression [119]-[125]. Both in rat and mouse liver, in vitro and in vivo administration of T3 lead to an increased $\beta$-catenin cytoplasmic stabilization and nuclear translocation, with concomitant increase in cyclin-D1 expression via $\beta$-catenin-TCF4. In contrast, liver from T3-treated mice did not exhibit changes in Ctnnb1 expression, but increased the $\beta$-catenin phosphorylation at Ser675, a downstream event of protein kinase A (PKA) pathway [126]. These results suggest T3 action on receptor tyrosine kinase (RTK) of cell membrane-possibly EGFR, insulin receptor IGF-1, etc. PKA activation, in turn, phosphorylates $\beta$-catenin for nuclear translocation and binding with TCF4, thereby modulating gene transcription, such as cyclin-D1 gene and others (Figure 2).

TH treatment also causes astrocytes differentiation through both an initial activation of PKA, with a peak activity at $2 \mathrm{~h}$, falling back to basal levels thereafter and a biphasic response on the cellular phospho-MAP kinase (p-MAPK or p-ERK) levels [127]. The induction was accompanied by a parallel increase in phospho-CREB activity, which, however, persisted at the end of the astroglia cells transformation [127]. Moreover, E-cadherin expression is highly and postnatally regulated in the peripheral nervous system in concert with the $\mathrm{N}$-cadherin disappearance and the development of myelinating Schwann cell lineage. Thus, E-cadherins maintain the structural integrity of noncompact myelin regions. The molecular signal that regulates the cadherin switch in Schwann cell is unclear but has been demonstrated that the axonal effect is mediated through cAMP-PKA activation-dependent of RTK activation [128].

Interesting, human RTK proteins are classified into 20 subfamilies based upon structural features in their extracellular regions, which include the cadherin domains, cysteine-rich domains, immunoglobulin-like domains, leucine-rich domains, Kringle domains, fibronectin type III repeats, discoidin I-like domains, acidic domains, and EGF-like domains [129].

Ligand binding to RTKs stimulates lateral contacts between a pair of EGFR molecules, resulting in EGFR dimerization mediated by interactions between extracellular regions, transmembrane domains, and cytoplasmic regions resulting in stimulation of tyrosine kinase activity and autophosphorylation by an intermolecular process [130]. RTKs recruit a variety of signaling molecules that stimulate the activities of a variety of intracellular signaling pathways including the RAS/MAPK, the PI-3K/Akt, and the Jak2/STAT pathways, among others [130].

It is known that EGF concentration is upregulated by exogenous T3 and developmentally regulated in mouse [131] and rat [132], showing even sex- and tissue-dependent opposite levels [131]. In rat, during the postnatal period, the TR $\beta$-mRNA levels first, and EGF-mRNA levels, afterwards, show a dramatical increase [132]. However, whereas the neonatal T4 treatment augmented the mRNA levels of EGF, it decreased the levels of EGF-receptor and did not signif- 
icantly affect the levels of mRNA for TR. In other studies, T3 induces the expression of full-length EGFR-mRNA and accelerates their turnover rate, apparently because the 3' end of full-length EGFR-mRNA has a role in their destabilization by T3, controlling cell proliferation. Results suggest that the mode of action of TH mediates the growth promoting and developmental effects by the transient induction of full-length EGF receptor, which is 3' truncated in hepatoma cells [133]. In contrast, T3 could operate as a cell proliferative agent through a mechanism involving an autocrine/paracrine EGF/EGFR-dependent tyrosine kinase regulation [134].

E-cadherin, in turn, can negatively regulate, in an adhesion-dependent manner, the ligand-dependent activation of divergent classes of RTKs [135], promoting cell differentiation.

It is evident that a cross talking between E-cadherin, EGF/EGFR, T3/TRs is necessary to modulate opposite and coordinate process such as cell proliferation and differentiation during tissue remodeling. The numerous data and cell context revisions show that $\mathrm{T} 3$ and its nuclear receptors modify expression of different genes/proteins involved in cell cycle control, from growth factors (such as EGF and TGF- $\beta$ ) to cell surface receptors (EGFR, E-cadherin), as well as proteins acting at the cell membrane (Ras), various transcription factors (c-Fos, c-Myc, E2F1, $\beta$-catenin, p53), cyclins, Cip/Kip family of cdk2 inhibitors, and p53 inhibitor Mdm2 [45] [46] [113] [136]. Therefore, the function of THs and their receptors on cell proliferation, differentiation, apoptosis/survival, adhesion and migration is not homogenous, because it strongly depends on the cell type, its developmental state (progenitor or differentiated), its pathophysiological state (normal or tumor cell), and the so-called "tissue and cellular context".

Although TH-dependent processes are highly coordinated, these are not necessarily synchronized in all tissues, and the proper function of the organism requires tissue-specific changes in $\mathrm{TH}$ action. These varying local requirements cannot be governed by global mechanisms such as an alteration of thyroid gland function or by modulation of hormone concentrations at plasma level, but instead require tissue-specific regulation, such as those mediated by deiodinases. Thus, the activation of the $\beta$-catenin/TCF complex and type 3 deiodinase (D3) expression, a selenoenzyme that inactivates $\mathrm{T} 3$, have been detected frequently in tumors [114]. Further, D3 is a direct transcriptional target of the $\beta$-catenin/TCF complex, increasing its expression in human intestinal adenomas and carcinomas, compared to healthy intestinal tissue [114]. Experimental attenuation of $\beta$-catenin reduces D3 levels and induces the type 2 deiodinase (D2), the D3 antagonist that converts T4 into active T3, thereby increasing T3-dependent transcription. In the absence of D3, a T3 excess causes the reduction of cell proliferation and promotes differentiation in cultured cells and in mouse xenograft models. This seems to occur via induction of E-cadherin, which sequester $\beta$-catenin at the plasma membrane promoting cell differentiation (Figure 1 and Figure 2). These results suggest that deiodinases could be at the interface between the 
$\beta$-catenin and the TH pathways. Dentice and coworkers sustain that the synchronized regulation of intracellular T3 concentration is a route by which the multiple effects of $\beta$-catenin are generated and may be targeted to reduce the oncogenic effects of it in intestinal cells.

Recently, we have implemented a murine model of colorectal cancer (CRC), in which four weeks post-induction, it is verified a slight increase of E-cadherin mRNA level, a significant decrease of $\beta$-catenin mRNA level and an almost constant $\alpha$-catenin mRNA level. Simultaneously, an extremely significant increase in RhoA mRNAs is produced, suggesting loss or weakening of adhesive bonds mediated by cadherin E. In vivo treatment with L-T4 does not seem to greatly influence the transcription of the genes responsible for cell adhesion mediated by E-cadherin-catenins, whereas impacted on RhoA, Rap1 and Cdc42 expression. Conversely, L-T4 produced a significant and very significant decrease in RTa and $\mathrm{RTb}$ respectively. While the cell differentiation marker (intestinal alkaline phosphatase) showed no changes, suggesting the maintenance of the intestinal phenotype at this stage of the CRC, there was a significant decrease in the PCNA and integrin $\alpha 5 \beta 3$ mRNAs, suggesting an effective role of L-T4 as pro-differentiating by controlling cell proliferation and migration. However, a striking and extremely significant positive effect on the expression of HIF1A was detected. Bioassays and complementary techniques will be necessary to analyze longer treatment times and the adhesive behavior, which depends on the concentration of cadherin $\mathrm{E}$ on the cell surface.

\subsection{E-Cadherin in Nontumoral Pathologies}

Between pathological states, reduced E-cadherin occurs in gastroesophageal reflux disease, asthma, and eczema, in which contributes to loss of epithelial integrity, impairment of barrier function, and production of pro-inflammatory cytokines [137] [138] [139]. E-cadherin binds lymphocyte integrin $\alpha \mathrm{E} \beta 7$ and regulates the activation and localization of epidermal and intestinal intraepithelial lymphocytes [140] [141] [142] [143]. Future studies will contribute to understand E-cadherin roles in immunology state.

\section{Conclusion}

Although E-cadherin and their partner components have been extensively studied, the majority has hardly been examined in the complexity of in vivo system. Thus, the E-cadherin function/dysfunction presented here should be regarded as a "work in progress". We strongly believe that the most interesting and important features of E-cadherin-dependent adhesions, consists in acting in a delicate balance between the cell motility inhibition and collective cell migration of cell clusters promotion. In these cellular contexts, thyroid hormones influence the differentiation and metabolic cell state, acting on E-cadherin receptor and gene. Knowing the role of thyroid hormones in the progress of cancer possess is a new challenge in the control of this disease. 


\section{Acknowledgements}

This study was supported by the grant PID-CYT-UNER 6164 (to M. F. Izaguirre).

\section{Conflicts of Interest}

The authors declare no conflicts of interest regarding the publication of this paper.

\section{References}

[1] Birchmeier, W. and Behrens, J. (1994) Cadherin Expression in Carcinomas: Role in the Formation of Cell Junctions and the Prevention of Invasiveness. Biochimica et Biophysica Acta, 1198, 11-26. https://doi.org/10.1016/0304-419X(94)90003-5

[2] Christofori, G. and Semb, H. (1999) The Role of the Cell-Adhesion Molecule E-Cadherin as a Tumour-Suppressor Gene. Trends in Biochemical Sciences, 24, 73-76. https://doi.org/10.1016/S0968-0004(98)01343-7

[3] Strumane, K., Berx, G. and van Roy, F. (2004) Cadherins in Cancer. In: Behrens, J. and Nelson, J., Eds., Cell Adhesion, Handbook of Experimental Pharmacology, Vol. 165, Springer-Verlag, Heidelberg, 69-103.

https://doi.org/10.1007/978-3-540-68170-0_4

[4] Berx, G. and van Roy, F. (2009) Involvement of Members of the Cadherin Superfamily in Cancer. Cold Spring Harbor Perspectives in Biology, 1, a003129. https://doi.org/10.1101/cshperspect.a003129

[5] Sundfeldt, K. (2003) Cell-Cell Adhesion in the Normal Ovary and Ovarian Tumors of Epithelial Origin; an Exception to the Rule. Molecular and Cellular Endocrinology, 202, 89-96. https://doi.org/10.1016/S0303-7207(03)00068-6

[6] Naora, H. and Montell, D.J. (2005) Ovarian Cancer Metastasis: Integrating Insights from Disparate Model Organisms. Nature Reviews Cancer, 5, 355-366. https://doi.org/10.1038/nrc1611

[7] Alpaugh, M.L., Tomlinson, J.S., Shao, Z.M. and Barsky, S.H. (1999) A Novel Human Xenograft Model of Inflammatory Breast Cancer. Cancer Research, 59, 5079-5084.

[8] Kleer, C.G., van Golen, K.L., Braun, T. and Merajver, S.D. (2001) Persistent E-Cadherin Expression in Inflammatory Breast Cancer. Modern Pathology, 14, 458-464. https://doi.org/10.1038/modpathol.3880334

[9] Yang, J. and Weinberg, R.A. (2008) Epithelial-Mesenchymal Transition: At the Crossroads of Development and Tumor Metastasis. Developmental Cell, 14, 818-829. https://doi.org/10.1016/j.devcel.2008.05.009

[10] Shamir, E.R., Pappalardo, E., Jorgens, D.M., Coutinho, K., Tsai, W.T. and Aziz, K. (2014) Twist-Induced Dissemination Preserves Epithelial Identity and Requires E-Cadherin. The Journal of Cell Biology, 204, 839-856. https://doi.org/10.1083/jcb.201306088

[11] Lou, Y., Preobrazhenska, O., auf dem Keller, U., Sutcliffe, M., Barclay, L., McDonald, P.C., Roskelley, C., Overall, C.M. and Dedhar, S. (2008) Epithelial-Mesenchymal Transition (EMT) Is Not Sufficient for Spontaneous Murine Breast Cancer Metastasis. Developmental Dynamics, 237, 2755-2768. https://doi.org/10.1002/dvdy.21658

[12] Hollestelle, A., Peeters, J.K., Smid, M., Timmermans, M., Verhoog, L.C., Westenend, P.J., Heine, A.A., Chan, A., Sieuwerts, A.M. and Wiemer, E.A. (2013) Loss of 
E-Cadherin Is Not a Necessity for Epithelial to Mesenchymal Transition in Human Breast Cancer. Breast Cancer Research and Treatment, 138, 47-57. https://doi.org/10.1007/s10549-013-2415-3

[13] Fischer, K.R., Durrans, A., Lee, S., Sheng, J., Li, F., Wong, S.T., Choi, H., El Rayes, T., Ryu, S., Troeger, J., Schwabe, R.F., Vahdat, L.T., Altorki, N.K., Mittal, V. and Gao, D. (2015) Epithelial-to-Mesenchymal Transition Is Not Required for Lung Metastasis But Contributes to Chemoresistance. Nature, 527, 472-476. https://doi.org/10.1038/nature15748

[14] Whittle, M.C. and Hingorani, S.R. (2015) Disconnect between EMT and Metastasis in Pancreas Cancer. Oncotarget, 6, 30445-30446. https://doi.org/10.18632/oncotarget.5720

[15] Zheng, X., Carstens, J.L., Kim, J., Scheible, M., Kaye, J., Sugimoto, H., Wu, C.C., LeBleu, V.S. and Kalluri, R. (2015) Epithelial-to-Mesenchymal Transition Is Dispensable for Metastasis But Induces Chemoresistance in Pancreatic Cancer. Nature, 527, 525-530. https://doi.org/10.1038/nature16064

[16] Aceto, N., Bardia, A., Miyamoto, D.T., Donaldson, M.C., Wittner, B.S., Spencer, J.A., Yu, M., Pely, A., Engstrom, A., Zhu, H., Brannigan, B.W., Kapur, R., Stott, S.L., Shioda, T., Ramaswamy, S., Ting, D.T., Lin, C.P., Toner, M., Haber, D.A. and Maheswaran, S. (2014) Circulating Tumor Cell Clusters Are Oligoclonal Precursors of Breast Cancer Metastasis. Cell, 158, 1110-1122.

https://doi.org/10.1016/j.cell.2014.07.013

[17] Cheung, K.J. and Ewald, A.J. (2016) A Collective Route to Metastasis: Seeding by Tumor Cell Clusters. Science, 352, 167-169. https://doi.org/10.1126/science.aaf6546

[18] Cheung, K.J., Gabrielson, E., Werb, Z. and Ewald, A.J. (2013) Collective Invasion in Breast Cancer Requires a Conserved Basal Epithelial Program. Cell, 155, 1639-1651. https://doi.org/10.1016/j.cell.2013.11.029

[19] Chung, Y.C., Wei, W.C., Hung, C.N., Kuo, J.F., Hsu, C.P., Chang, K.J. and Chao, W.T. (2016) Rab11 Collaborates E-Cadherin to Promote Collective Cell Migration and Indicates a Poor Prognosis in Colorectal Carcinoma. European Journal of Clinical Investigation, 46, 1002-1011. https://doi.org/10.1111/eci.12683

[20] Petrova, Y.I., Schecterson, L. and Gumbiner, B.M. (2016) Roles for E-Cadherin Cell Surface Regulation in Cancer. Molecular Biology of the Cell, 27, 3233-3244. https://doi.org/10.1091/mbc.E16-01-0058

[21] Petrova, Y.I., Spano, M.M. and Gumbiner, B.M. (2012) Conformational Epitopes at Cadherin Calcium-Binding Sites and p120-Catenin Phosphorylation Regulate Cell Adhesion. Molecular Biology of the Cell, 23, 2092-2108. https://doi.org/10.1091/mbc.e11-12-1060

[22] Shashikanth, N., Petrova, Y.I., Park, S., Chekan, J., Maiden, S., Spano, M., Ha, T., Gumbiner, B.M. and Leckband, D.E. (2015) Allosteric Regulation of E-Cadherin Adhesion. Journal of Biological Chemistry, 290, 21749-21761. https://doi.org/10.1074/jbc.M115.657098

[23] Maiden, S.L., Petrova, Y.I. and Gumbiner, B.M. (2016) Microtubules Inhibit E-Cadherin Adhesive Activity by Maintaining Phosphorylated p120-Catenin in a Colon Carcinoma Cell Model. PLoS ONE, 11, e0148574. https://doi.org/10.1371/journal.pone.0148574

[24] Brieher, W.M. and Gumbiner, B.M. (1994) Regulation of Cadherin Function during Activin Induced Morphogenesis of Xenopus Animal Caps. Journal of Cell Biology, 126, 519-527. https://doi.org/10.1083/jcb.126.2.519

[25] Zhong, Y., Brieher, W.M. and Gumbiner, B.M. (1999) Analysis of C-Cadherin Reg- 
ulation during Tissue Morphogenesis with an Activating Antibody. Journal of Cell Biology, 144, 351-359. https://doi.org/10.1083/jcb.144.2.351

[26] Shamir, E.R. and Ewald, A.J. (2015) Adhesion in Mammary Development: Novel Roles for E-Cadherin in Individual and Collective Cell Migration. Current Topics in Developmental Biology, 112, 353-382. https://doi.org/10.1016/bs.ctdb.2014.12.001

[27] Tanos, B. and Rodriguez-Boulan, E. (2008) The Epithelial Polarity Program: Machineries Involved and Their Hijacking by Cancer. Oncogene, 27, 6939-6957. https://doi.org/10.1038/onc.2008.345

[28] Ozawa, M., Engel, J. and Kemler, R. (1990) Single Amino Acid Substitutions in One $\mathrm{Ca}^{2+}$ Binding Site of Uvomorulin Abolish the Adhesive Function. Cell, 63, 1033-1038. https://doi.org/10.1016/0092-8674(90)90506-A

[29] Takeichi, M. (1991) Cadherin Cell Adhesion Receptors as a Morphogenetic Regulator. Science, 251, 1451-1455. https://doi.org/10.1126/science.2006419

[30] Pokutta, S., Herrenknecht, K., Kemler, R. and Engel, J. (1994) Conformational Changes of the Recombinant Extracellular Domain of E-Cadherin upon Calcium Binding. European Journal of Biochemistry, 223, 1019-1026. https://doi.org/10.1111/j.1432-1033.1994.tb19080.x

[31] Pertz, O., Bozic, D., Koch, A.W., Fauser, C., Brancaccio, A. and Engel, J. (1999) A New Crystal Structure, $\mathrm{Ca}^{2+}$ Dependence and Mutational Analysis Reveal Molecular Details of E-Cadherin Homoassociation. EMBO Journal, 18, 1738-1747. https://doi.org/10.1093/emboj/18.7.1738

[32] Luber, B., Candidus, S., Handschuh, G., Mentele, E., Hutzler, P., Feller, S., Voss, J., Höfler, H. and Becker, K.F. (2000) Tumor-Derived Mutated E-Cadherin Influences $\beta$-Catenin Localization and Increases Susceptibility to Actin Cytoskeletal Changes Induced by Pervanadate. Cell Adhesion and Communication, 7, 391-408. https://doi.org/10.3109/15419060009109021

[33] Simões-Correia, J., Figueiredo, J., Oliveira, C., van Hengel, J., Seruca, R., van Roy, F. and Suriano, G. (2008) Endoplasmic Reticulum Quality Control: A New Mechanism of E-Cadherin Regulation and Its Implication in Cancer. Human Molecular Genetics, 17, 3566-3576. https://doi.org/10.1093/hmg/ddn249

[34] Baum, B. and Perrimon, N. (2001) Spatial Control of the Actin Cytoskeleton in Drosophila Epithelial Cells. Nature Cell Biology, 3, 883-890. https://doi.org/10.1038/ncb1001-883

[35] Perez-Moreno, M., Jamora, C. and Fuchs, E. (2003) Sticky Business: Orchestrating Cellular Signals at Adherens Junctions. Cell, 112, 535-548. https://doi.org/10.1016/S0092-8674(03)00108-9

[36] Drees, F., Pokutta, S., Yamada, S., Nelson, W.J. and Weis, W.I. (2005) Alpha-Catenin Is a Molecular Switch That Binds E-Cadherin- $\beta$-Catenin and Regulates Actin-Filament Assembly. Cell, 123, 903-915.

https://doi.org/10.1016/j.cell.2005.09.021

[37] Rivard, N. (2009) Phosphatidylinositol 3-Kinase: A Key Regulator in Adherens Junction Formation and Function. Frontiers in Bioscience, 14, 510-522. https://doi.org/10.2741/3259

[38] Meng, W., Mushika, Y., Ichii, T. and Takeichi, M. (2008) Anchorage of Microtubule Minus Ends to Adherens Junctions Regulates Epithelial Cell-Cell Contacts. Cell. 135, 948-959. https://doi.org/10.1016/j.cell.2008.09.040

[39] Meng, W. and Takeichi, M. (2009) Adherens Junction: Molecular Architecture and Regulation. Cold Spring Harbor Perspectives in Biology, 1, a002899. https://doi.org/10.1101/cshperspect.a002899 
[40] Laprise, P., Chailler, P., Houde, M., Beaulieu, J.F., Boucher, M.J. and Rivard, N. (2002) Phosphatidylinositol 3-Kinase Controls Human Intestinal Epithelial Cell Differentiation by Promoting Adherens Junction Assembly and p38 MAPK Activation. Journal of Biological Chemistry, 277, 8226-8234. https://doi.org/10.1074/jbc.M110235200

[41] Taddei, A., Giampietro, C., Conti, A., Orsenigo, F., Breviario, F., Pirazzoli, V., Potente, M., Daly, C., Dimmeler, S. and Dejana, E. (2008) Endothelial Adherens Junctions Control Tight Junctions by VE-Cadherin-Mediated Upregulation of Claudin. Nature Cell Biology, 10, 923-934. https://doi.org/10.1038/ncb1752

[42] le Duc, Q., Shi, Q., Blonk, I., Sonnenberg, A., Wang, N., Leckband, D. and de Rooij, J. (2010) Vinculin Potentiates E-Cadherin Mechanosensing and Is Recruited to Actin-Anchored Sites within Adherens Junctions in a Myosin II-Dependent Manner. Journal of Cell Biology, 189, 1107-1115. https://doi.org/10.1083/jcb.201001149

[43] Yonemura, S., Wada, Y., Watanabe, T., Nagafuchi, A. and Shibata, M. (2010) $\alpha$-Catenin as a Tension Transducer That Induces Adherens Junction Development. Nature Cell Biology, 12, 533-542. https://doi.org/10.1038/ncb2055

[44] Izaguirre, M.F., Larrea, D., Adur, J.F., Diaz-Zamboni, J.E., Vicente, N., Galetto, C.D. and Casco, V.H. (2010) E-Cadherin Role in Epithelial Architecture Maintenance. Cell Communication \& Adhesion, 17, 1-12. https://doi.org/10.3109/15419061003686938

[45] Izaguirre, M.F. and Casco, V.H. (2010) T3 Regulates E-Cadherin, and $\beta$ - and $\alpha$-Catenin Expression in the Stomach during the Metamorphosis of the Toad Rhinella arenarum. Biotechnic Histochemistry (USA), 85, 305-323. https://doi.org/10.3109/10520290903236005

[46] Izaguirre, M.F. and Casco, V.H. (2016) E-Cadherin Roles in Animal Biology: A Perspective on Thyroid Hormone-Influence. Cell Communication \& Signaling, 14, 27. https://doi.org/10.1186/s12964-016-0150-1

[47] Pećina-Šlaus, N. (2003) Tumor Suppressor Gene E-Cadherin and Its Role in Normal and Malignant Cells. Cancer Cell International, 3, 17. https://doi.org/10.1186/1475-2867-3-17

[48] van Roy, F. and Berx, G. (2008) The Cell-Cell Adhesion Molecule E-Cadherin. Cellular and Molecular Life Sciences, 65, 3756-3788. https://doi.org/10.1007/s00018-008-8281-1

[49] Becker, K.F., Atkinson, M.J., Reich, U., Becker, I., Nekarda, H., Siewert, J.R. and Höfler, H. (1994) E-Cadherin Gene Mutations Provide Clues to Diffuse Type Gastric Carcinomas. Cancer Research, 54, 3845-3852.

[50] Berx, G., Becker, K.F., Hofler, H. and van Roy, F. (1998) Mutations of the Human E-Cadherin (CDH1) Gene. Human Mutation, 12, 226-237. https://doi.org/10.1002/(SICI)1098-1004(1998)12:4<226::AID-HUMU2>3.0.CO;2$\underline{\mathrm{D}}$

[51] Guilford, P., Hopkins, J., Harraway, J., McLeod, M., McLeod, N., Harawira, P., Taite, H., Scoular, R., Miller, A. and Reeve, A.E. (1998) E-Cadherin Germline Mutations in Familial Gastric Cancer. Nature, 392, 402-405. https://doi.org/10.1038/32918

[52] Richards, F.M., McKee, S.A., Rajpar, M.H., Cole, T.R.P., Evans, D.G.R., Jankowski, J.A., McKeown, C., Sanders, D.S.A. and Maher, E.R. (1999) Germline E-Cadherin Gene (CDH1) Mutations Predispose to Familial Gastric Cancer and Colorectal Cancer. Human Molecular Genetics, 8, 607-610. https://doi.org/10.1093/hmg/8.4.607 
[53] Chun, Y.S., Lindor, N.M., Smyrk, T.C., Petersen, B.T., Burgart, L.J., Guilford, P.J. and Donohue, J.H. (2001) Germline E-Cadherin Gene Mutations: Is Prophylactic Total Gastrectomy Indicated? Cancer, 92, 181-187. https://doi.org/10.1002/1097-0142(20010701)92:1<181::AID-CNCR1307>3.0.CO;2-J

[54] Gayther, S.A., Gorringe, K.L., Ramus, S.J., Huntsman, D., Roviello, F., Grehan, N., Machado, J.C., Pinto, E., Seruca, R., Halling, K. and MacLeod, P. (1999) Germline E-Cadherin Gene (CDH1) Mutations Predispose to Familial Gastric Cancer and Colorectal Cancer. Human Molecular Genetics, 8, 607-610. https://doi.org/10.1093/hmg/8.4.607

[55] Gamboa-Dominguez, A., Dominguez-Fonseca, C., Chavarri-Guerra, Y., Vargas, R., Reyes-Gutierrez, E., Green, D., Quintanilla-Martinez, L., Luber, B., Busch, R., Becker, K.F., Becker, I., Höfler, H. and Fend, F. (2005) E-Cadherin Expression in Sporadic Gastric Cancer from Mexico: Exon 8 and 9 Deletions Are Infrequent Events Associated with Poor Survival. Human Pathology, 36, 29-35.

https://doi.org/10.1016/j.humpath.2004.09.020

[56] Muta, H., Noguchi, M., Kanai, Y., Ochiai, A., Nawata, H. and Hirohashi, S. (1996) E-Cadherin Gene Mutations in Signet Ring Cell Carcinoma of the Stomach. Japanese Journal of Cancer Research, 87, 843-848. https://doi.org/10.1111/j.1349-7006.1996.tb02109.x

[57] Guilford, P.J., Hopkins, J.B., Grady, W.M., Markowitz, S.D., Willis, J., Lynch, H., Rajput, A., Wiesner, G.L., Lindor, N.M., Burgart, L.J., Toro, T.T., Lee, D., Limacher, J.M., Shaw, D.W., Findlay, M.P. and Reeve, A.E. (1999) E-Cadherin Germline Mutations Define an Inherited Cancer Syndrome Dominated by Diffuse Gastric Cancer. Human Mutation, 14, 249-255.

https://doi.org/10.1002/(SICI)1098-1004(1999)14:3<249::AID-HUMU8>3.0.CO;2-9

[58] Humar, B., Blair, V., Charlton, A., More, H., Martin, I. and Guilford, P. (2009) E-Cadherin Deficiency Initiates Gastric Signet-Ring Cell Carcinoma in Mice and Man. Cancer Research, 69, 2050-2056. https://doi.org/10.1158/0008-5472.CAN-08-2457

[59] Handschuh, G., Candidus, S., Luber, B., Reich, U., Schott, C., Oswald, S., Becke, H., Hutzler, P., Birchmeier, W., Höfler, H. and Becker, K.F. (1999) Tumour-Associated E-Cadherin Mutations Alter Cellular Morphology, Decrease Cellular Adhesion and Increase Cellular Motility. Oncogene, 18, 4301-4312. https://doi.org/10.1038/sj.onc.1202790

[60] Handschuh, G., Luber, B., Hutzler, P., Höfler, H. and Becker, K.F. (2001) Single Amino Acid Substitutions in Conserved Extracellular Domains of E-Cadherin Differ in Their Functional Consequences. Journal of Molecular Biology, 314, 445-454. https://doi.org/10.1006/jmbi.2001.5143

[61] Nagafuchi, A., Shirayoshi, Y., Okazaki, K., Yasuda, K. and Takeichi, M. (1987) Transformation of Cell Adhesion Properties by Exogenously Introduced E-Cadherin cDNA. Nature, 329, 341-343. https://doi.org/10.1038/329341a0

[62] Behrens, J., Mareel, M.M., Van Roy, F.M. and Birchmeier, W. (1989) Dissecting Tumor Cell Invasion: Epithelial Cells Acquire Invasive Properties after the Loss of Uvomorulin-Mediated Cell-Cell Adhesion. Journal of Cell Biology, 108, 2435-2447. https://doi.org/10.1083/jcb.108.6.2435

[63] Vleminckx, K., Vakaet, L., Mareel, M., Fiers, W. and van Roy, F. (1991) Genetic Manipulation of E-Cadherin Expression by Epithelial Tumor Cells Reveals an Invasion Suppressor Role. Cell, 66, 107-119. https://doi.org/10.1016/0092-8674(91)90143-M

[64] Frixen, U.H., Behrens, J., Sachs, M., Eberle, G., Voss, B., Warda, A., Löchner, D. and 
Birchmeier, W. (1991) E-Cadherin-Mediated Cell-Cell Adhesion Prevents Invasiveness of Human Carcinoma Cells. Journal of Cellular Biology, 113, 173-185. https://doi.org/10.1083/jcb.113.1.173

[65] Sharma, S. and Lichtenstein, A. (2009) Aberrant Splicing of the E-Cadherin Transcript Is a Novel Mechanism of Gene Silencing in Chronic Lymphocytic Leukemia Cells. Blood, 114, 4179-4185. https://doi.org/10.1182/blood-2009-03-206482

[66] Culbertson, M.R. (1999) RNA Surveillance. Unforeseen Consequences for Gene Expression, Inherited Genetic Disorders and Cancer. Trends in Genetics, 15, 74-80. https://doi.org/10.1016/S0168-9525(98)01658-8

[67] Frischmeyer, P.A., van Hoof, A., O’Donnell, K., Guerrerio, A.L., Parker, R. and Dietz, H.C. (2002) An mRNA Surveillance Mechanism That Eliminates Transcripts Lacking Termination Codons. Science, 295, 2258-2261.

https://doi.org/10.1126/science.1067338

[68] Chang, Y.F., Imam, J.S. and Wilkinson, M.F. (2007) The Nonsense-Mediated Decay RNA Surveillance Pathway. Annual Review of Biochemistry, 76, 51-74.

https://doi.org/10.1146/annurev.biochem.76.050106.093909

[69] Sharma, S., Liao, W., Zhou, X., Wong, D.T. and Lichtenstein, A. (2011) Exon 11 Skipping of E-Cadherin RNA Downregulates Its Expression in Head and Neck Cancer Cells. Molecular Cancer Therapeutics, 10, 1751-1759. https://doi.org/10.1158/1535-7163.MCT-11-0248

[70] Hyafil, F., Morello, D., Babinet, C. and Jacob, F. (1980) A Cell Surface Glycoprotein Involved in the Compaction of Embryonal Carcinoma Cells and Cleavage Stage Embryos. Cell, 21, 927-934. https://doi.org/10.1016/0092-8674(80)90456-0

[71] Sefton, M., Johnson, M.H. and Clayton, L. (1992) Synthesis and Phosphorylation of Uvomorulin during Mouse Early Development. Development, 115, 313-318.

[72] Stephenson, R.O., Yamanaka, Y. and Rossant, J. (2010) Disorganized Epithelial Polarity and Excess Trophectoderm Cell Fate in Preimplantation Embryos Lacking E-Cadherin. Development, 137, 3383-3391. https://doi.org/10.1242/dev.050195

[73] Stemmler, M.P. (2008) Cadherins in Development and Cancer. Molecular Biosystems, 4, 835-850. https://doi.org/10.1039/b719215k

[74] Wheelock, M.J., Shintani, Y., Maeda, M., Fukumoto, Y. and Johnson, K.R. (2008) Cadherin Switching. Journal of Cell Science, 121, 727. https://doi.org/10.1242/jcs.000455

[75] Larue, L., Ohsugi, M., Hirchenhain, J. and Kemler, R. (1994) E-Cadherin Null Mutant Embryos Fail to Form a Trophectoderm Epithelium. Proceedings of the National Academy of Sciences of the United States of America, 91, 8263-8267. https://doi.org/10.1073/pnas.91.17.8263

[76] Riethmacher, D., Brinkmann, V. and Birchmeier, C. (1995) A Targeted Mutation in the Mouse E-Cadherin Gene Results in Defective Preimplantation Development. Proceedings of the National Academy of Sciences of the United States of America, 92, 855-859. https://doi.org/10.1073/pnas.92.3.855

[77] Boussadia, O., Kutsch, S., Hierholzer, A., Delmas, V. and Kemler, R. (2002) E-Cadherin Is a Survival Factor for the Lactating Mouse Mammary Gland. $\mathrm{Me}$ chanisms of Development, 115, 53-62. https://doi.org/10.1016/S0925-4773(02)00090-4

[78] Young, P., Boussadia, O., Halfter, H., Grose, R., Berger, P., Leone, D.P., Robenek, H., Charnay, P., Kemler, R. and Suter, U. (2003a) E-Cadherin Controls Adherens Junctions in the Epidermis and the Renewal of Hair Follicles. EMBO Journal, 22, 5723-5733. https://doi.org/10.1093/emboj/cdg560 
[79] Tinkle, C.L., Lechler, T., Pasolli, H.A. and Fuchs, E. (2004) Conditional Targeting of E-Cadherin in Skin: Insights into Hyperproliferative and Degenerative Responses. Proceedings of the National Academy of Sciences of the United States of America, 101, 552-557. https://doi.org/10.1073/pnas.0307437100

[80] Tinkle, C.L., Pasolli, H.A., Stokes, N. and Fuchs, E. (2008) New Insights into Cadherin Function in Epidermal Sheet Formation and Maintenance of Tissue Integrity. Proceedings of the National Academy of Sciences of the United States of America, 105, 15405-15410. https://doi.org/10.1073/pnas.0807374105

[81] Tunggal, J.A., Helfrich, I., Schmitz, A., Schwarz, H., Gunzel, D., Fromm, M., Kemler, R., Krieg, T. and Niessen, C.M. (2005) E-Cadherin Is Essential for in Vivo Epidermal Barrier Function by Regulating Tight Junctions. EMBO Journal, 24, 1146-1156. https://doi.org/10.1038/sj.emboj.7600605

[82] Calì, G., Zannini, M., Rubini, P., Tacchetti, C., D’Andrea, B., Affuso, A., Wintermantel, T., Boussadia, O., Terracciano, D., Silberschmidt, D., Amendola, E., De Felice, M., Schütz, G., Kemler, R., Di Lauro, R. and Nitsch, L. (2007) Conditional Inactivation of the E-Cadherin Gene in Thyroid Follicular Cells Affects Gland Development But Does Not Impair Junction Formation. Endocrinology, 148, 2737-2746. https://doi.org/10.1210/en.2006-1344

[83] Derksen, P.W., Liu, X., Saridin, F., van der Gulden, H., Zevenhoven, J., Evers, B., van Beijnum, J.R., Griffioen, A.W., Vink, J., Krimpenfort, P., Peterse, J.L., Cardiff, R.D., Berns, A. and Jonkers, J. (2006) Somatic Inactivation of E-Cadherin and p53 in Mice Leads to Metastatic Lobular Mammary Carcinoma through Induction of Anoikis Resistance and Angiogenesis. Cancer Cell, 10, 437-449. https://doi.org/10.1016/j.ccr.2006.09.013

[84] Gumbiner, B., Stevenson, B. and Grimaldi, A. (1988) The Role of the Cell Adhesion Molecule Uvomorulin in the Formation and Maintenance of the Epithelial Junctional Complex. Journal of Cellular Biology, 107, 1575-1587. https://doi.org/10.1083/jcb.107.4.1575

[85] Watabe, M., Nagafuchi, A., Tsukita, S. and Takeichi, M. (1994) Induction of Polarized Cell-Cell Association and Retardation of Growth by Activation of the E-Cadherin-Catenin Adhesion System in a Dispersed Carcinoma Line. Journal of Cell Biology, 127, 247-256. https://doi.org/10.1083/jcb.127.1.247

[86] Roitbak, T., Ward, C.J., Harris, P.C., Bacallao, R., Ness, S.A. and WandingerNess, A. (2004) A Polycystin-1 Multiprotein Complex Is Disrupted in Polycystic Kidney Disease Cells. Molecular Biology of the Cell, 15, 1334-1346. https://doi.org/10.1091/mbc.e03-05-0296

[87] Fujita, Y., Krause, G., Scheffner, M., Zechner, D., Leddy, H.E., Behrens, J., Sommer, T. and Birchmeier, W. (2002) Hakai, a c-Cbl-like Protein, Ubiquitinates and Induces Endocytosis of the E-Cadherin Complex. Nature Cell Biology, 4, 222-231. https://doi.org/10.1038/ncb758

[88] Palovuori, R., Sormunen, R. and Eskelinen, S. (2003) Src-Induced Disintegration of Adherens Junctions of Madin-Darby Canine Kidney Cells Is Dependent on Endocytosis of Cadherin and Antagonized by Tiam-1. Laboratory Investigation, 83, 1901-1915. https://doi.org/10.1097/01.LAB.0000107009.75152.03

[89] Delva, E. and Kowalczyk, A.P. (2009) Regulation of Cadherin Trafficking. Traffic, 10, 259-267. https://doi.org/10.1111/j.1600-0854.2008.00862.x

[90] Palacios, F., Tushir, J.S., Fujita, Y. and D’Souza-Schorey, C. (2005) Lysosomal Targeting of E-Cadherin: A Unique Mechanism for the Down-Regulation of Cell-Cell Adhesion during Epithelial to Mesenchymal Transitions. Molecular and Cellular 
Biology, 25, 389-402. https://doi.org/10.1128/MCB.25.1.389-402.2005

[91] Janda, E., Nevolo, M., Lehmann, K., Downward, J., Beug, H. and Grieco, M. (2006) Raf plus TGFbeta-Dependent EMT Is Initiated by Endocytosis and Lysosomal Degradation of E-Cadherin. Oncogene, 25, 7117-7130.

https://doi.org/10.1038/sj.onc.1209701

[92] Shen, Y., Hirsch, D.S., Sasiela, C.A. and Wu, W.J. (2008) Cdc42 Regulates E-Cadherin Ubiquitination and Degradation through an Epidermal Growth Factor Receptor to Src-Mediated Pathway. Journal of Biological Chemistry, 283, 5127-5137. https://doi.org/10.1074/jbc.M703300200

[93] Casco, V.H., Izaguirre, M.F. and Paz, D.A. (1998) Efecto de los Anticuerpos anti a-Catenina sobre la Embriogénesis de Bufo arenarum. Boletín de la Sociedad Biológica de Concepción, 69, 55-61.

[94] Izaguirre, M.F., Adur, J.F., Peralta Soler, A. and Casco, V.H. (2001) Alterations Induced by E-Cadherin and $\beta$-Catenin Antibodies during the Development of Bufo arenarum (Anura: Bufonidae). Histology \& Histopathology, 16, 1097-1106.

[95] Izaguirre, M.F. and Casco, V.H. (2011) Adhesión intercelular en el desarrollo de vertebrados. Su rol en el desarrollo embrionario y larval de anfibios. Editorial Académica Española, Saarbrücken.

[96] Nagaoka, M., Koshimizu, U., Yuasa, S., Hattori, F., Chen, H., Tanaka, T., Okabe, M., Fukuda, K. and Akaike, T. (2006) E-Cadherin-Coated Plates Maintain Pluripotent ES Cells without Colony Formation. PLoS ONE, 1, e15. https://doi.org/10.1371/journal.pone.0000015

[97] Li, D., Zhou, J., Wang, L., Shin, M.E., Su, P., Lei, X., Kuang, H., Guo, W., Yang, H., Cheng, L., Tanaka, T.S., Leckband, D.E., Reynolds, A.B., Duan, E. and Wang, F. (2010) Integrated Biochemical and Mechanical Signals Regulate Multifaceted Human Embryonic Stem Cell Functions. Journal of Cell Biology, 191, 631-644. https://doi.org/10.1083/jcb.201006094

[98] Li, L., Wang, S., Jezierski, A., Moalim-Nour, L., Mohib, K., Parks, R.J., Retta, S.F. and Wang, L. (2010) A Unique Interplay between Rap1 and E-Cadherin in the Endocytic Pathway Regulates Self-Renewal of Human Embryonic Stem Cells. Stem Cells, 28, 247-57. https://doi.org/10.1002/stem.289

[99] Ji, Y. and Tulin, A.V. (2012) Poly(ADP-Ribose) Controls DE-Cadherin-Dependent Stem Cell Maintenance and Oocyte Localization. Nature Communications, 3, 760. https://doi.org/10.1038/ncomms1759

[100] del Valle, I., Rudloff, S., Carles, A., Li, Y., Liszewska, E., Vogt, R. and Kemler, R. (2013) E-Cadherin Is Required for the Proper Activation of the Lifr/Gp130 Signaling Pathway in Mouse Embryonic Stem Cells. Development, 140, 1684-1692. https://doi.org/10.1242/dev.088690

[101] Perret, E., Leung, A., Feracci, H. and Evans, E. (2004) Trans-Bonded Pairs of E-Cadherin Exhibit a Remarkable Hierarchy of Mechanical Strengths. Proceedings of the National Academy of Sciences of the United States of America, 47, 16472-16477. https://doi.org/10.1073/pnas.0402085101

[102] Pokutta, S. and Weis, W.I. (2007) Structure and Mechanism of Cadherins and Catenins in Cell-Cell Contacts. Annual Review of Cell and Developmental Biology, 23, 237-261. https://doi.org/10.1146/annurev.cellbio.22.010305.104241

[103] Kusumi, A., Suzuki, K. and Koyasako, K. (1999) Mobility and Cytoeskeletal Interactions of Cell Adhesion Receptors. Current Opinion in Cell Biology, 11, 582-590. https://doi.org/10.1016/S0955-0674(99)00020-4

[104] Bayas, M.V., Leung, A., Evans, E. and Leckband, D. (2006) Lifetime Measurements 
Reveal Kinetic Differences between Homophilic Cadherin Bonds. Biophysical Journal, 90, 1385-1395. https://doi.org/10.1529/biophysj.105.069583

[105] Wheelock, M.J., Kundsen, K.A. and Johnson, K.R. (1996) Membrane-Cytoskeleton Interaction with Cadherin Cell Adhesion Proteins: Roles of Catenins as Linker Proteins. Current Topics in Membranes, 43, 169-185. https://doi.org/10.1016/S0070-2161(08)60389-5

[106] Xu, W. and Kimelman, D. (2007) Mechanistic Insights from Structural Studies of Beta-Catenin and Its Binding Partners. Journal of Cell Science, 120, 3337-3344. https://doi.org/10.1242/jcs.013771

[107] Müller, T., Choidas, A., Reichmann, E. and Ullrich, A. (1999) Phosphorylation and Free Pool of Beta-Catenin Are Regulated by Tyrosine Kinases and Tyrosine Phosphatases during Epithelial Cell Migration. Journal of Biological Chemistry, 274, 10173-10183. https://doi.org/10.1074/jbc.274.15.10173

[108] Miller, J.R. and Moon, R.T. (1996) Signal Transduction through $\beta$-Catenin and Specification of Cell Fate during Embryogenesis. Genes \& Development, 10, 2527-2539. https://doi.org/10.1101/gad.10.20.2527

[109] Willert, K. and Jones, K.A. (2006) Wnt Signaling: Is the Party in the Nucleus? Genes \& Development, 20, 1394-1404. https://doi.org/10.1101/gad.1424006

[110] Young, B.A., Sui, X., Kiser, T.D., Hyun, S.W., Wang, P., Sakarya, S., Angelini, D.J., Schaphorst, K.L., Hasday, J.D., Cross, A.S., Romer, L.H., Passaniti, A. and Goldblum, S.E. (2003b) Protein Tyrosine Phosphatase Activity Regulates Endothelial Cell-Cell Interactions, the Paracellular Pathway, and Capillary Tube Stability. American Journal of Physiology-Lung Cellular and Molecular Physiology, 285, L63-L75. https://doi.org/10.1152/ajplung.00423.2002

[111] Galetto, C.D. (2016) Rol de la adhesión mediada por cadherina-E. PhD Thesis on Biological Sciences, School of Biochemistry and Biological Sciences of the Litoral National University, Argentina.

[112] Galetto, C.D., Izaguirre, M.F. and Casco, V.H. (2017) In Vivo Study of Epithelial Adhesion via E-Cadherin $\beta$ - and $\alpha$-Catenin-Small GTP-Binding Proteins under T3 Regulation. Journal of Cell Signaling, 2, 1.

[113] Plateroti, M., Kress, E., Mori, J.I. and Samarut, J. (2006) Thyroid Hormone Receptor Alpha1 Directly Controls Transcription of the Beta-Catenin Gene in Intestinal Epithelial Cells. Molecular and Cellular Biology, 26, 3204-3214. https://doi.org/10.1128/MCB.26.8.3204-3214.2006

[114] Dentice, M., Luongo, C., Ambrosio, R., Sibilio, A., Casillo, A., Iaccarino, A., Troncone, G., Fenzi, G., Larsen, P.R. and Salvatore, D. (2012) $\beta$-Catenin Regulates Deiodinase Levels and Thyroid Hormone Signaling in Colon Cancer Cells. Gastroenterology, 143, 1037-1047. https://doi.org/10.1053/j.gastro.2012.06.042

[115] Sirakov, M. and Plateroti, M. (2011) The Thyroid Hormones and Their Nuclear Receptors in the Gut: From Developmental Biology to Cancer. Biochimica et Biophysica Acta, 1812, 938-946. https://doi.org/10.1016/j.bbadis.2010.12.020

[116] Sirakov, M., Skah, S., Lone, I.N., Nadjar, J., Angelov, D. and Plateroti, M. (2012) Multi-Level Interactions between the Nuclear Receptor TR $\alpha 1$ and the WNT Effectors $\beta$-Catenin/Tcf4 in the Intestinal Epithelium. PLOS ONE, 7, e34162. https://doi.org/10.1371/journal.pone.0034162

[117] Guigon, C.J., Kim, D.W., Zhu, X., Zhao, L. and Cheng, S.Y. (2010) Tumor Suppressor Action of Liganded Thyroid Hormone Receptor Beta by Direct Repression of Beta-Catenin Gene Expression. Endocrinology, 151, 5528-5536. https://doi.org/10.1210/en.2010-0475 
[118] Buchholz, D.R., Heimeier, R.A., Biswajit, D., Washington, T. and Shi, Y.-B. (2007) Pairing Morphology with Gene Expression in Thyroid Hormone-Induced Intestinal Remodeling and Identification of a Core Set of TH-Induced Genes across Tadpole Tissues. Developmental Biology, 303, 576-590. https://doi.org/10.1016/j.ydbio.2006.11.037

[119] Hanley, K., Rassner, U., Elias, P.M., Williams, M.L. and Feingold, K.R. (1996) Epidermal Barrier Ontogenesis: Maturation in Serum-Free Media and Acceleration by Glucocorticoids and Thyroid Hormone But Not Selected Growth Factors. Journal of Investigative Dermatology, 106, 404-411. https://doi.org/10.1111/1523-1747.ep12343405

[120] Tomic-Canic, M., Day, D., Samuels, H.H., Freedberg, I.M. and Blumenberg, M. (1996) Novel Regulation of Keratin Gene Expression by Thyroid Hormone and Retinoid Receptors. Journal of Biological Chemistry, 271, 1416-1423. https://doi.org/10.1074/jbc.271.3.1416

[121] Komuves, L.G., Hanley, K., Jiang, Y., Elias, P.M., Williams, M.L. and Feingold, K.R. (1998) Ligands and Activators of Nuclear Hormone Receptors Regulate Epidermal Differentiation during Fetal Rat Skin Development. Journal of Investigative Dermatology, 111, 429-433. https://doi.org/10.1046/j.1523-1747.1998.00296.x

[122] Slominski, A. and Wortsman, J. (2000) Neuroendocrinology of the Skin. Endocrine Reviews, 21, 457-487. https://doi.org/10.1210/er.21.5.457

[123] Leonhardt, J.M. and Heymann, W.R. (2002) Thyroid Disease and the Skin. Dermatologic Clinics, 20, 473-481. https://doi.org/10.1016/S0733-8635(02)00009-8

[124] Radoja, N., Stojadinovic, O., Waseem, A., Tomic-Canic, M., Milisavljevic, V., Teebor, S. and Blumenberg, M. (2004) Thyroid Hormones and Gamma Interferon Specifically Increase K15 Keratin Gene Transcription. Molecular and Cellular Biology, 24, 3168-3179. https://doi.org/10.1128/MCB.24.8.3168-3179.2004

[125] Safer, J.D., Crawford, T.M. and Holick, M.F. (2004) A Role for Thyroid Hormone in Wound Healing through Keratin Gene Expression. Endocrinology, 145, 2357-2361. https://doi.org/10.1210/en.2003-1696

[126] Fanti, M., Singh, S., Ledda-Columbano, G.M., Columbano, A. and Monga, S.P. (2014) Tri-Iodothyronine Induces Hepatocyte Proliferation by Protein Kinase A-Dependent $\beta$-Catenin Activation in Rodents. Hepatology, 59, 2309-2320. https://doi.org/10.1002/hep.26775

[127] Ghosh, M., Gharami, K., Paul, S. and Das, S. (2005) Thyroid Hormone-Induced Morphological Differentiation and Maturation of Astrocytes Involves Activation of Protein Kinase A and ERK Signalling Pathway. European Journal of Neuroscience, 22, 1609-1617. https://doi.org/10.1111/j.1460-9568.2005.04351.x

[128] Crawford, A.T., Desai, D., Gokina, P., Basak, S. and Kim, H.A. (2008) E-Cadherin Expression in Postnatal Schwann Cells Is Regulated by the cAMP-Dependent Protein Kinase A Pathway. Glia, 56, 1637-1647. https://doi.org/10.1002/glia.20716

[129] Lemmon, M.A. and Schlessinger, J. (2010) Cell Signaling by Receptor Tyrosine Kinases. Cell, 141, 1117-1134. https://doi.org/10.1016/j.cell.2010.06.011

[130] Schlessinger, J. (2014) Receptor Tyrosine Kinases: Legacy of the First Two Decades. Cold Spring Harbor Perspectives in Biology, 6, a008912. https://doi.org/10.1101/cshperspect.a008912

[131] Gubits, R.M., Shaw, P.A., Gresik, E.W., Onetti-Muda, A. and Barka, T. (1986) Epidermal Growth Factor Gene Expression Is Regulated Differently in Mouse Kidney and Submandibular Gland. Endocrinology, 119, 1382-1387.

https://doi.org/10.1210/endo-119-3-1382 
[132] North, D., Lakshmanan, J., Reviczky, A., Kaser, M. and Fisher, D.A. (1992) Ontogeny of Epidermal Growth Factor, Transforming Growth Factor- $\alpha$, Epidermal Growth Factor Receptor, and Thyroid Hormone Receptor RNA Levels in Rat Kidney and Changes in Those Levels Induced by Early Thyroxine Treatment. Pediatric Research, 31, 330-334. https://doi.org/10.1203/00006450-199204000-00005

[133] Satoh, Y. and Sairenji, T. (1997) Regulation of the Expression of Epidermal Growth Factor Receptor mRNA with Thyroid Hormone L-3,5,3'-Triiodothyronine in Rat Hepatoma Cells. Yonago Acta Medica, 40, 133-136.

[134] Di Fulvio, M., Coleoni, A.H., Pellizas, C.G. and Masini-Repiso, A.M. (2000) Tri-Iodothyronine Induces Proliferation in Cultured Bovine Thyroid Cells: Evidence for the Involvement of Epidermal Growth Factor-Associated Tyrosine Kinase Activity. Journal of Endocrinology, 166, 173-182. https://doi.org/10.1677/joe.0.1660173

[135] Qian, X., Karpova, T., Sheppard, A.M., McNally, J. and Lowy, D.R. (2004) E-Cadherin-Mediated Adhesion Inhibits Ligand-Dependent Activation of Diverse Receptor Tyrosine Kinases. EMBO Journal, 23, 1739-1748. https://doi.org/10.1038/sj.emboj.7600136

[136] Puzianowska-Kuznicka, M., Pietrzak, M., Turowska, O. and Nauman, A. (2006) Thyroid Hormones and Their Receptors in the Regulation of Cell Proliferation. Acta Biochimica Polonica, 53, 641-650.

[137] Trautmann, A., Altznauer, F., Akdis, M., Simon, H.U., Blaser, K., Akdis, C.A. and Bröcker, E.B. (2001) The Differential Fate of Cadherins during T-Cell-Induced Keratinocyte Apoptosis Leads to Spongiosis in Eczematous Dermatitis. Journal of Investigative Dermatology, 117, 927-934. https://doi.org/10.1046/j.0022-202x.2001.01474.x

[138] Trautmann, A., Kruger, K., Akdis, M., Muller-Wening, D., Akkaya, A., Brocker, E.B., Blaser, K. and Akdis, C.A. (2005) Apoptosis and Loss of Adhesion of Bronchial Epithelial Cells in Asthma. International Archives of Allergy and Immunology, 138, 142-150. https://doi.org/10.1159/000088436

[139] Heijink, I.H., Kies, P.M., Kauffman, H.F., Postma, D.S., van Oosterhout, A.J. and Vellenga, E. (2007) Down-Regulation of E-Cadherin in Human Bronchial Epithelial Cells Leads to Epidermal Growth Factor Receptor-Dependent Th2 Cell-Promoting Activity. Journal of Immunology, 178, 7678-7685. https://doi.org/10.4049/jimmunol.178.12.7678

[140] Cepek, K.L., Parker, C.M., Madara, J.L. and Brenner, M.B. (1993) Integrin Alpha E Beta 7 Mediates Adhesion of T Lymphocytes to Epithelial Cells. Journal of Immunology, 150, 3459-3470.

[141] Cepek, K.L., Shaw, S.K., Parker, C.M., Russell, G.J., Morrow, J.S., Rimm, D.L. and Brenner, M.B. (1994) Adhesion between Epithelial Cells and T Lymphocytes Mediated by E-Cadherin and the Alpha E Beta 7 Integrin. Nature, 372, 190-193. https://doi.org/10.1038/372190a0

[142] Schön, M.P., Arya, A., Murphy, E.A., Adams, C.M., Strauch, U.G., Agace, W.W., Marsal, J., Donohue, J.P., Her, H., Beier, D.R., Olson, S., Lefrancois, L., Brenner, M.B., Grusby, M.J. and Parker, C.M. (1999) Mucosal T Lymphocyte Numbers Are Selectively Reduced in Integrin Alpha E (CD103)-Deficient Mice. Journal of Immunology, 162, 6641-6649.

[143] Uchida, Y., Kawai, K., Ibusuki, A. and Kanekura, T. (2011) Role for E-Cadherin as an Inhibitory Receptor on Epidermal Gammadelta T Cells. Journal of Immunology, 186, 6945-6954. https://doi.org/10.4049/jimmunol.1003853 
[144] El Rebey, H.S., Maree, A.H., El Tahmody, M. and Abdel Naby, H. (2014) Role of E-Cadherin in Psoriasis. Egyptian Journal of Pathology, 34, 148-154.

https://doi.org/10.1097/01.XEJ.0000455929.33903.19 